Article

\title{
Climate Change Adaptation Tools at the Community Level: An Integrated Literature Review
}

\author{
Elvis Modikela Nkoana ${ }^{1,2, *}$, Aviel Verbruggen ${ }^{3}$ and Jean Hugé ${ }^{4,5,6}$ \\ 1 Institute of Environment and Sustainable Development (IMDO), University of Antwerp, Universiteitsplein 1, \\ Antwerp 2610, Belgium \\ 2 College of Education, University of South Africa, Pretoria 0003, South Africa \\ 3 Department of Economics, University of Antwerp, Stadscampus-Building B, Room B.216, Prinsstraat 13, \\ Antwerp BE-2000, Belgium; aviel.verbruggen@ua.ac.be \\ 4 Centre for Sustainable Development, University of Ghent, Ghent 9000, Belgium; Jean.Huge@ulb.ac.be \\ 5 Centre for Environmental Science, University of Hasselt, Hasselt 3500, Belgium \\ 6 Systems Ecology \& Resources Management Unit, Universite Libre de Bruxelles, Brussels 1050, Belgium \\ * Correspondence: nkoana.elvis6@gmail.com
}

Received: 6 December 2017; Accepted: 6 March 2018; Published: 13 March 2018

\begin{abstract}
The negative impacts of climate change are experienced at the global, regional and local levels. However, rural communities in sub-Saharan Africa face additional socio-political, cultural and economic challenges in addition to climate change. Decision support tools have been developed and applied to assist rural communities to cope with and adapt to climate change. However, poorly planned participatory processes and the lack of context-specific approaches in these tools are obstacles when aiming at strengthening the resilience of these rural communities. This paper uses an integrated literature review to identify best practices for involving rural communities in climate change adaptation efforts through the application of context-specific and culturally-sensitive climate change adaptation tools. These best practices include the use of a livelihoods approach to engage communities; the explicit acknowledgement of the local cultural do's and don'ts; the recognition of local champions appointed from within the local community; the identification and prioritisation of vulnerable stakeholders; and the implementation of a two-way climate change risk communication instead of a one-sided information sharing approach.
\end{abstract}

Keywords: climate change adaptation tools; design considerations; rural communities; sub-Saharan Africa

\section{Introduction}

Climate change-induced natural hazards increase both in magnitude and frequency, thereby threatening the stability and sustainability of social-ecological systems. Society has to adapt its economic, institutional, political and social practices in order to protect the physical environment on which it depends from anthropogenic climate change [1]. Global responses to man-made climate change focus on adaptation and mitigation efforts. Planned adaptation efforts are geared towards minimizing the risk of an already occurring climate change, while taking advantage of associated opportunities [2]. Incidental adaptation [3] is unplanned and its actors might not even be aware of it. Mitigation involves the reduction of anthropogenic greenhouse gas emissions, which has recently gained momentum at the global level thanks to the so-called Paris Agreement [4].

All actors and sectors have to adapt to and mitigate the negative impacts of climate change $[1,5]$. However, climate actions are fraught with complexities and uncertainties [6] which has led to the emergence of decision support tools (DST) in the fields of environmental management [7], disaster risk reduction [8-10] and impact assessment [7,11-18]. These tools use a transdisciplinary approach 
that fosters collaboration between scientists, practitioners and local communities in order to address climate change. Transdisciplinarity (TD) is an approach that involves different disciplines as well as scientific and non-scientific stakeholders collaborating to address socially relevant problems, through joint knowledge integration and mutual learning. The aim is to produce "socially robust knowledge" that is both scientifically valuable and relevant for societal progress [19-23]. However, the uptake of decision support tools by non-scientific stakeholders (local communities) is challenging due to many factors (including prohibitive financial cost, top-down design of the tools, poorly designed participation processes and technical complexity). This explains the low uptake of decision support tools by local communities, especially in developing countries $[7,18]$.

Climate adaptation tools have been developed and applied by bilateral, multilateral and non-governmental development organizations [24,25]. The majority of these tools are developed by European and North American institutions including the United Kingdom Department for International Development (DFID), the United States Agency for International Development (USAID) and international not-for-profit organizations such as the Catholic Relief Services, Red Cross/Crescent and ActionAid [26]. However a nexus of historical, socio-political, cultural and economic factors [7] may hinder the effective use of climate adaptation tools by rural communities in developing countries.

This paper uses an integrated literature review to highlight key contextually-driven and culturally-sensitive factors that should ideally be acknowledged when designing and applying climate change adaptation tools in rural communities in sub-Saharan African.

\section{Methodology}

First, the contextual factors we report on in this paper were deduced from scientific literature reporting on climate change adaptation at the rural community level in the global South. These literature sources were gathered through an integrative literature review process, which describes and synthesizes knowledge from past empirical and/or theoretical literature sources $[27,28]$. The objective of this integrated literature review is to target representative literature sources rather than drawing a comprehensive review as is the case in a systematic literature review $[27,29]$.

Second, we identified and accessed climate change adaptation tools $(n=49)$ through online searches using a range of websites of international development organizations (such as the Danish International Development Agency (DANIDA), the German Technical Cooperation Agency (GTZ), United Nations (UN) agencies, the United States Agency for International Development (USAID), the UK Department for International Development (DFID), the World Bank etc.) as well as through Google web browsing. We used the following key search words: "Climate Change Adaptation Tools" (see Appendix A for a full list of considered climate change adaptation tools).

Third, a Boolean search was conducted on Google Scholar between January and October 2017 using these key search words: Local knowledge AND Climate change AND Africa; Livelihoods AND Climate change adaptation AND Africa; Community based adaptation AND climate change; Community adaptation AND Climate change; and Participatory climate change adaptation. This search yielded scientific literature $(n=70)$ reporting on climate adaptation specificities in a rural community context in the global South.

Fourth, the literature was analyzed and synthesized though qualitative content analysis to deduce the contextual factors that should be considered when designing and applying climate adaptation tools in rural communities in the global South. Qualitative content analysis systematically describes the meaning of qualitative data [27]. This method is both systematic, reductionist and flexible. It is systematic in that it follows a step-by-step iterative process. It also reduces large volumes of data by deriving meanings of passages and elevating them to higher levels of abstraction through a coding frame. Its flexibility lies in its ability combine varying portions of concept-driven and data-driven categories within any one coding frame [30]. Hence, this study organized large volumes of qualitative data into themes and sub-themes that form the structure of this paper. The themes are the following: 
- Planning, designing and implementing climate change adaptation tools at the rural community level

- Considerations when planning the participation process at the rural community level

- Context-specificity

Socio-economic and Livelihoods context

Socio-political and cultural context

- Objectives-clarity and Stakeholder identification and management

Clarifying the objectives of the participation process

Identifying stakeholders for the participation process

- Considerations when designing the participation process at the rural community level

Oral narratives

PRA, CRA and VCA tools and techniques

Participatory mapping

- Considerations when implementing the participation processes at the rural community level

- Risk communication

Information-sharing

Extraction

- Participatory modelling and scenarios building at the rural community level

Participatory modelling

Scenarios building

- Assessing the sustainability of climate adaptation action plans

Fifth, a supplementary backward snowballing exercise was conducted, which revealed scientific literature publications by leading authors in Environmental Decision Support Systems (EDSS) and Environmental Decision Support Tools (EDST) including Matthies et al. [31], McIntosh et al. [7] and Sullivan [32]. In addition, articles from leading journals on indigenous knowledge science, including Climatic Change and Indilinga: African Journal of Indigenous Knowledge Systems, were considered in the analysis.

Fifth, a supplementary backward snowballing exercise was conducted, which revealed scientific literature publications by leading authors in Environmental Decision Support Systems (EDSS) and Environmental Decision Support Tools (EDST) including Matthies et al. [31], McIntosh et al. [7] and Sullivan [32]. In addition, articles from leading journals on indigenous knowledge science, including Climatic Change and Indilinga: African Journal of Indigenous Knowledge Systems, were considered in the analysis.

Sixth, we selected reports emanating from international development cooperation organizations from the following sources:

- Reports on indigenous knowledge practices: ACIA [33]; IPCC, [5]; IUCN, [34]; UNESCO, [35]; and FAO [36].

- Conference proceedings on environmental modelling: International Congress on Environmental Modelling and Software (iEMS). (URL Link: http:/ /www.iemss.org/sites/iemss2016/).

Lastly, we excluded books and articles published outside of the sub-Saharan African context and those that were not published in English. 


\section{Planning, Designing and Implementing Climate Change Adaptation Tools at the Rural Community Level}

Based on the integrative review outlined in Section 2, this section discusses the various factors that should be taken into consideration when planning, designing and implementing climate change adaptation tools in a rural community context in sub-Saharan Africa.

\subsection{Considerations When Planning the Participation Process at the Rural Community Level}

\subsubsection{Context-Specificity}

The majority of climate adaptation tools is influenced by Western worldviews [37]. The importance of context is highlighted by empirical studies on climate adaptation in Africa (see [6,38-47]). In the following paragraphs, we discuss the contextual dimensions that influence climate adaptation efforts in sub-Saharan African communities.

\section{Socio-Economic and Livelihoods Context}

The majority of sub-Saharan African citizens reside in rural areas and they are directly dependent on agrarian activities including subsistence rain-fed agriculture $[38,42,48,49]$ and livestock rearing $[50,51]$. Rain-fed agriculture is especially susceptible to climate change [48]. The vulnerability of rural communities is further exacerbated by non-climatic stressors such as poverty [43] and the HIV / AIDS pandemic [47,50]. Hence, climate change and development are interconnected [52]. It is this reality that compels the incorporation of socio-economic and livelihoods considerations in the design and implementation of climate change adaptation tools. This reality has now started to influence the work of development cooperation organizations [6]. Framing climate change adaptation efforts within a socio-economic and livelihoods context has many benefits, including increased acceptability and ownership by rural communities, which is key to overcome public resistance to perceived external interference. Moreover, this inclusive approach ensures that resources are devoted to the socio-economic development of rural communities as climate adaptation does not merely bring challenges but also socio-economic opportunities [2]. Such opportunities are recognized and institutionalized at the national, regional and local levels. For example, the growth and development strategy of South Africa-the National Development Plan 2030-prescribes that the government and its agencies (including those tasks with environmental protection) have to address the triple challenges of inequality, poverty and unemployment [53]. This is a reflection that local communities' priorities mostly revolve around 'everyday problems' and their constant struggle with their maintenance of livelihoods [6].

\section{Socio-Political and Cultural Context}

"What people know is influenced by (and influences) their beliefs, lifestyle and behavior. To understand local knowledge one has to understand and account for people's ways of knowing (i.e. different knowledge types) as much as their practices and beliefs, perceptions and values. Understanding all this is crucial because it can explain why people do things the way they do" [54] (p. 21).

This quote illustrates the importance of local beliefs, customs and traditions, as these are the lenses through which rural communities see the world. These lenses govern the decisions they make on a daily basis. Such decisions include climate adaptation and mitigation actions using information derived from their own local climate monitoring mechanisms. Simply put, local knowledge is defined as institutionalized knowledge that has been accumulated from interactions with the local environment over a long period of time and that has been passed on from one generation to the other by word of mouth" [45] (p. 792). Local knowledge serves as a local framework for decision making in rural and urban communities $[43,45,46,55,56]$. Despite this, Nyong et al. [45] (p. 794) notes that "development 
projects are known to have been created, funded and managed by outside resources and introduced into rural communities with the hopes and promises of impacting lives. These projects did not take into consideration the culture of people and resulted in low participation and success rates".

The limited success of many climate-centered development cooperation projects does not come as a surprise when decision makers (policy makers, scientist and practitioners) apply adaptation tools that are poorly designed to engage local communities [26]. These decision makers are often 'out of touch' with the realities of rural life. Van Aalst et al. [6] found that decision makers are often baffled by the risk and adaptation priorities of local communities which are often shaped by the immediate socio-economic, political and cultural contexts $[46,55,56]$.

Elders are sought after as custodians of local knowledge due to their age and long-term interaction with their local environment $[37,39,41,42,45,53-55]$. As such, they are seen as experts, gatekeepers and go-between in local decision-making matters. Their position of authority is confirmed by purposive sampling targeting community elders in indigenous knowledge studies conducted by Nkomwa et al. [38]; Ifejika-Speranza et al. [43]. Their communities rely on them to pass on specialist local knowledge on climate monitoring, adaptation and mitigation to the younger generations [54]. As gatekeepers, community elders are the go-to individuals when planning development cooperation work in their local communities. The role of community elders as go-betweens has many aspects including in organizing and leading traditional rituals such as rain making ceremonies. Traditional beliefs are very important to rural life and together with local knowledge, form a traditional institutionalized decision-making framework. For example, Egeru [40]; Mengistu [42]; Ifejika-Speranza [43]; Roncoli et al. [46]; Lemos et al. [54] and Luseno et al. [55] found that traditional beliefs were significant factors affecting the uptake of local and scientific climate forecasts by rural communities. Such beliefs reiterate the importance of acknowledging different worldviews, particularly those that are not shaped by Western knowledge. Such worldviews emerge from the local knowledge of rural communities accumulated overtime and based on interactions with their environment. These alternative worldviews should be acknowledged by development cooperation practitioners designing and implementing climate adaptation tools in rural communities (see [37]).

In this regard, the roles of community elders have to be acknowledged and their participation as local champions and knowledge brokers in the development of decision support tools should be encouraged. A 'local champion' is an individual who is trained and appointed from within an organization to maintain user engagement with the decision support tool(s) [43] (p. 279). Similarly, local experts within rural communities can be 'trained' and 'appointed' to work alongside community members, scientist and practitioners using mediums suitable for a local audience including the local language $[43,56]$.

The institutionalisation of climate change planning and management in eThekwini municipality (City of Durban) was spearheaded by the head of the Environmental Management Department after participating in a semester-long environmental management program at Brown University in Rhodes Island (USA) in 2004. This local champion established the Municipal Climate Protection Program (MPCC) [57] (p. 527) that commissioned assessment studies on the local impacts of climate change on various sectors and actors in the eThekwini municipal area entitled Climatic Future for Durban. The outcomes of the impact assessment studies laid a solid foundation for localised adaptation plans highlighted in the Headline Adaptation Strategy and later the Municipal Adaptation Plans (MAPs). The MAPs are "sectoral adaptation plans focused on the biodiversity, health, water and disaster management sectors" [58] (pp. 1, 62) resulting in forty-seven (47) discrete adaptation options across these sectors [59]. This example, although set in an urban context, can get us thinking about the lessons we can draw from the involvement of local champions in adaptation endeavours. Empirical studies are still required on the experiences of involving local champions in a rural context.

The case study referred to in the previous paragraph is evidence that involving a local champion can encourage the take up of climate adaptation efforts at the local level. 


\subsubsection{Objectives-Clarity and Stakeholder Identification and Management}

\section{Clarifying the Objectives of the Participation Process}

Clarifying the objectives at the beginning of any climate adaptation effort helps with identifying stakeholders and managing their expectations. Local communities have the right to know and understand the purpose of any climate adaptation effort in their community. This will enable them to gauge the level of their involvement and/or commitment. By doing so, local communities can also develop realistic expectations regarding the benefits they can derive out of such adaptation efforts. Benefits do not always entail material gains but can revolve around new knowledge, skills and techniques. We have developed a participation typology that can be useful in guiding the planning, development and implementation of climate adaptation tools. The typology is presented in Table 1 and explained in a subsequent paragraph.

Table 1. Typology for participation in the context of community-based climate change adaptation.

\begin{tabular}{llll}
\hline $\begin{array}{c}\text { Stages of Participation } \\
\text { (i.e., Degree of } \\
\begin{array}{c}\text { Participation/Rungs of } \\
\text { Arnstein's Ladder) }\end{array}\end{array}$ & $\begin{array}{c}\text { Main Purpose of } \\
\text { Participation } \\
\text { (i.e., Objectives } \\
\text { of Participation) }\end{array}$ & $\begin{array}{c}\text { Characteristics of the Stage } \\
\text { (i.e., Direction of } \\
\text { Communication Flows) }\end{array}$ & $\begin{array}{c}\text { Type of Participation } \\
\text { (i.e., Theoretical } \\
\text { Basis/Pragmatic } \\
\text { Participation etc.) }\end{array}$ \\
\hline Information-sharing & Information & $\begin{array}{l}\text { Information flows in one } \\
\text { direction from the practitioners to } \\
\text { the local community } \\
\text { Information flows in one } \\
\text { direction from the local } \\
\text { community to the practitioners }\end{array}$ & Passive participation \\
Consultation & Extraction & $\begin{array}{l}\text { Flow of information is arranged } \\
\text { in both directions: from the } \\
\text { local community to the } \\
\text { practitioners and vice versa- in } \\
\text { a process of shared learning }\end{array}$ & Interactive participation \\
\hline Co-decision & reciprocity of actions) & \\
\hline Decision & Ownership & $\begin{array}{l}\text { The local community becomes } \\
\text { responsible for the planning, } \\
\text { design and implementation of } \\
\text { climate adaptation action plans }\end{array}$ & $\begin{array}{l}\text { Active participation/ } \\
\text { self-organization/ } \\
\text { citizens control }\end{array}$ \\
\hline
\end{tabular}

Source: adapted from Nkoana et al. [20].

The typology for public participation can include subject (objective) of participation, communication (information and/or extraction), type (passive, interactive, and/or active) and the stages of participation. The types and objectives of the projects at-hand determine the type and the degree of participation by local communities [60]. This is evidence that the 'one-size-fits-all' approach does not work in participation. It is for this reason that the authors have developed a participation typology for climate adaptation tools. The purpose of participation within this is sharing information (scientific data and local observations) about climate change, consultation to build consensus about the reality of climate change between practitioners and the local community, co-development of climate adaptation action plans and lastly, decision about implementation and ownership of the adaptation action plans by the local community. This typology of community-based climate adaptation is based on all three participation principles namely normative, substantive and instrumental $[60,61]$. The normativity principle argues that the local communities have the right to participate in climate adaptation efforts in their localities. The substantive principle posits that the quality of the participatory process is improved with the involvement of various players including the local community members. The instrumental principle states that participation improves trust and acceptance of subsequent decisions [56]. The participation typology also covers crucial areas of participation including: stages, purpose, characteristics and type of participation. Practitioners should consult this participation typology when planning, designing and implementing climate adaptation tools with local communities. 
Identifying Stakeholders for the Participation Process

Practitioners can move on to classify stakeholders once the objectives of the climate adaptation effort have been established. Stakeholder classification allows to identify groups that are particularly vulnerable to climate change impacts and variability, Nkoana et al. [26] have developed a stakeholder classification typology presented in Table 2. This stakeholder classification typology consists of top-down and bottom-up approaches. The top-down approaches are exclusively initiated by practitioners and the bottom-up approaches are pioneered with the assistance of local communities.

Table 2. Common stakeholder classification typologies.

\begin{tabular}{|c|c|}
\hline Classification/Criteria Used (Models/Methods) & \\
\hline $\begin{array}{l}\text { Stakeholder's levels of interest and influence } \\
\text { (Interest \& Influence Matrix) [62] }\end{array}$ & \multirow{11}{*}{$\begin{array}{l}\text { Top-down approaches } \\
\text { "Analytical Categorization" }\end{array}$} \\
\hline Competition or cooperation $[63,64]$ & \\
\hline The strategic and the moral stakeholder [65] & \\
\hline $\begin{array}{l}\text { Stakeholder's potential powers to threaten or cooperate with the } \\
\text { organization (cooperation and threat) [66] }\end{array}$ & \\
\hline $\begin{array}{l}\text { The primary (with formal relationships) and the secondary } \\
\text { (without formal relationships) [67] }\end{array}$ & \\
\hline Power, legitimacy and urgency (Stakeholder Salience Model) [68] & \\
\hline Network density and the centrality of the organization focus [69] & \\
\hline $\begin{array}{l}\text { Power of influence, impact on the organization and affinity with } \\
\text { organizational objectives [70] }\end{array}$ & \\
\hline Power and the level of interest [71] & \\
\hline $\begin{array}{l}\text { Degree stakeholders affect or can be affected by problem or } \\
\text { action-with a Rainbow Diagram [72] }\end{array}$ & \\
\hline Classical stakeholders, stakewatchers, stakekeepers [73] & \\
\hline Discourse Analysis-with a Q methodology [74-79] & Bottom-Up "Reconstructive Methods" \\
\hline
\end{tabular}

Source: Nkoana et al. [20].

Once the stakeholders have been classified using one or a combination of the classification typologies, the next step is to identify stakeholders that should be involved in the climate adaptation effort. Reed et al. [16] summarizes the methods that can be used to identify, differentiate, categorize and investigate relationships between stakeholders (see Table 3).

Table 3. Summary of various top-down and bottom-up methods used to identify, differentiate, categorizes and investigate relationships between stakeholders.

\begin{tabular}{lll}
\hline \multicolumn{1}{c}{ Identify Stakeholders } & Differentiate \& Categorize Stakeholders & $\begin{array}{c}\text { Investigate Relationships } \\
\text { between Stakeholders }\end{array}$ \\
\hline Self-selection & Top-down Analytical Categorization using: & \\
Expert Opinion & Interest-Influence matrices & \\
Focus Groups & Radical Transactiveness & \\
Semi-structured interviews & Bottom-up Stakeholder-led Stakeholder & Actor-Linkage matrices \\
Snowball Sampling & Categorization: & Social Network Analysis \\
Demographic data (age, gender, & Card Sorting & Knowledge Mapping \\
nationality, residence, & Q Methodology & \\
occupation etc.) & Q sorting & \\
& Strategic Perspectives Analysis & \\
\hline
\end{tabular}




\subsection{Considerations When Designing the Participation Process at the Rural Community Level}

The planning phase is followed by the actual design of the participation process. Local communities have to be involved in all the stages of environmental management initiatives in their localities [35]. Full participation can be realized through the integration of local and scientific knowledge systems through forms and formats that are familiar to the local communities. This approach is crucial when considering the skepticism surrounding 'standalone' local knowledge systems [42,43]. Such skepticism compels practitioners to work alongside local communities to merge these two knowledge systems. However, the process of involving local communities in such efforts obliges us to think critically about the design of these interventions-including on these forms and formats. A few studies exist on the forms and formats for soliciting local knowledge (see $[6,80]$ ) because this field of study is still in its embryonic stage. As a consequence, we focus on Oral narratives, Participatory Rural Appraisal (PRA), Community Risk Assessment (CRA) and Vulnerability and Capacity Assessment (VCA) tool and techniques and the use of Visual images to engage local community members in climate adaptation efforts.

\subsubsection{Oral Narratives}

Narratives are used to solicit local knowledge seen through cosmological and weather observations and changes in the local environment, flora and fauna (see Table 4 below). These changes and observations include, erratic behaviour and irregular migration of animals, variable rainfall, wind direction, moon cycles, encounters with rare and exotic species, increased mosquito numbers and frequent cases of water-borne diseases and malaria outbreaks [38,40-42].

\subsubsection{PRA, CRA and VCA Tools and Technique}

However, narratives are only a small part of participatory techniques that can be used to involve local communities in climate monitoring, adaptation and mitigation efforts. Dominant participatory forms and formats such as Participatory Rural Appraisal (PRA) [81,82], Community Risk Assessment (CRA) [6] and Vulnerability and Capacity Assessment (VCA) [83] enjoy widespread application in international and regional NGOs sectors doing disaster preparedness work in rural communities in over eighty (80) countries across the world. Van Aalst et al. [6] (p. 166) note this trend that "international NGOs such as Oxfam, ActionAid, Save the Children, Christian Aid, Tearfund; developing country NGOs such as Citizen's Disaster Response Centre (Philippines); Third World networks such as La Red (in Latin America), PeriPeri (in southern Africa), Duryog Nivaran (in south Asia); and other organizations like the Asian Disaster Preparedness Centre, Disaster Reduction Unit, as well as umbrellas like the ProVention Consortium and the UN ISDR (International Strategy for Disaster Reduction)" use grassroots strategies that share elements of CRA, VCA and PRA. These elements involve place-based and bottom-up approaches that increase the resilience of rural communities through disaster preparedness and livelihoods diversification. Most, if not all, of these NGOs and multilateral and bilateral development cooperation organizations use document-based decision support tools-in the form of climate change adaptation and disaster preparedness tools-with PRA leaning methods and tools. Sometimes the tools are not exclusively directed at climate change adaptation and mitigation but also at disaster preparedness.

These methods and tools can include but are not limited to, transect walks, participatory mapping (resource and social maps), geographic maps (topographical maps), concept mapping, Venn diagrams, seasonal calendars, historical timeline and trend-line, problem tree, community hazard and vulnerability scoring and ranking matrices, semi-structured interviews, focus group discussions, mobility diagram, wealth ranking, gender daily calendars and future-backward scenarios analysis $[81,84]$ and so forth.

The use of such participatory methods and tools is resource intensive. However, it is key to apply these tools with a large number of community members, in order to derive meaningful and scalable results [6]. Low-tech methods and tools are crucial for engaging rural communities despite 
their resource intensity. In fact, computer-based environmental decision support tools are not cheap either and have been known to intimidate end-users including the educated elite [18].

\subsubsection{Participatory Mapping}

Participatory mapping is a common technique used in CRA, VCA and PRA exercises with rural communities. Visual images of aspects relevant to the local community are often the end-products of focus group activities using such participatory mapping techniques. However, Bell and Morse [85] warn about the uncritical use of participatory mapping and suggest a 'Subjective Assessment of Group Analysis', an assessment framework consisting of indicators to improve the quality of the mapping process and results, which, in turn, increases the credibility of the participation process and method applied (see Table 2 in [85]).

\subsection{Considerations When Implementing the Participation Processes at the Rural Community Level}

Participation of local communities should take center stage when implementing climate adaptation tools. Participation is important for normativity, substantive and instrumental reasons but also because solutions to wicked problems will require the involvement of those that understand the local context and cultures within which such changes occur. Climate adaptation tools should involve local communities through risk communication, vulnerability and impact assessment, adaptation assessment and sustainability assessment. There are claims that the participation of local communities might lead to high quality and robust decision-making that increases the resilience of social-ecological systems to climate change [61,86]. Nkoana et al. [26] found that climate adaptation tools are poorly designed to involve rural communities in adaptation efforts. We highlight the important considerations that should be heeded when implementing climate adaptation tools in rural communities in sub-Saharan Africa.

\subsubsection{Risk Communication}

Communication of climate change risk is an important step when implementing adaptation tools $[42,87,88]$, as local communities have to perceive risk before they can act to protect themselves against it. However, climate change is an abstract concept and is often considered to be a remote problem of little personal concern to many individuals [40,87-89], despite the fact that unplanned or incidental adaptation is already occurring in many rural communities [38,40,41,45,90]. Risk communication can bridge the gap between incidental and planned adaptation in rural communities in sub-Saharan Africa. However, careful considerations have to be heeded when designing risk communication messages in a rural context. For example, risk communication efforts have to demonstrate the localized impacts of climate change on rural communities. In doing so, practitioners have to recognize that climate risk communication is a two-ways process characterized by information-sharing and extraction [26]. Information-sharing is when practitioners share scientific data on climate change hazards and impacts with the local communities. Extraction happens when practitioners solicit local knowledge about climate change hazards from rural communities. This two-way dialogue is crucial for building consensus about the reality of climate change hazards and impacts at the local community level. Linking local knowledge to climate change science is a viable way to involve local communities [43]. Additionally, this two-ways process creates a participation platform that is important for instrumental, normativity and substantive reasons $[60,61]$.

\section{Information-Sharing}

Mengistu [42] points out that improving access to climate information is an important first step to improving the livelihood of people affected by climate change. Also, climate information is crucial in the context of "low grassroots awareness or campaigning on issues of climate change" [6] (p. 170). However, there are many factors that have to be taken into account when delivering a climate risk information message intended at local communities, especially since climate information 
which feed into decision-making is not suitable for most resource poor communities if created for a developed country's context [42]. These factors can include the various media of communication that are accessible to local communities, the participation platforms, and tools and the socio-political and cultural context including the language of the communication that is understood by the local communities. In this regard, practitioners conducting a climate risk information-sharing exercise should link their message with the day-to-day activities of the rural community members. This will make the climate risk message of local and individual relevance. Nicholson-Cole [88] suggests a clear criterion that can be useful in the visual communication of climate change to rural communities. An important message that can be derived from this author's work is that climate risk communication has to resonate with rural communities' experiences and motivate-rather than discourage them-to make adaptation actions, of course, this is also dependent on objective versus subjective (individual and collective) adaptive capacity of the local community members. Some of Nicholson-Cole's criterion including using locally sourced 'emotive' imagery; the careful design of risk communication message that does not "end up triggering defensive psychological responses, leaving the audience desensitized with a sense of 'issue fatigue' or leading to feelings of powerlessness to do anything to reduce the causes of climate change" [88] (p. 260) or anxiety and fatalism [6]; understanding of the local community context including customs and culture that act as socio-psychological lenses through which local communities interpret risk communication messages; and the use of a simple and easy to understand communication language [88]-particularly in rural communities with low literacy levels-a sobering reality for many sub-Saharan African countries. Information-sharing inevitably involves a top-down approach that is triggered and led by outsiders-an oxymoron in a process that is supposedly bottom-up. But Rojas Blanco (quoted in [6]) reassures us that "Not only do local communities have the right to be informed about the ramifications of climate change but also they are capable of generating solutions likely to work at their level".

\section{Extraction}

Extraction involves exercises in which practitioners solicit information and knowledge about climate change from local community members [26]. Local knowledge is often associated with rural communities, however, urban dwellers can also possess such knowledge as Codjoe et al. [39] found out. In this regard, there is a wealth of evidence on the role of local knowledge in incidental and planned climate adaptation in rural and urban communities all over the world [41]-including those in sub-Saharan Africa [38-40,42,43,45,90-92]. Local knowledge exists in many different forms. However, local ecological knowledge is the popular form that is associated with the natural environment. In this regard, local ecological knowledge refers to common and specialist knowledge that is location and culture-specific, is acquired through long-term interaction and observation of the natural environment (i.e., changes in flora, fauna, sea and weather conditions and astronomy constellations) and is passed down through oral traditions from one generation to another [39-42]. Local ecological knowledge-a form of local knowledge-is concerned with how people manage their natural resources. Just like other forms of local knowledge, local ecological knowledge is passed on from generation to generation through word of mouth [39-42]. Appreciating the inter-generational transfer of environmental observations through narratives represents an entry point on how climate adaptation tools can engage local communities in planned adaptation efforts [42], a subject we raised in the previous sections. Additionally, local ecological knowledge can be an important source of environmental observations particularly in African regions with limited instrumental records [41]. Such a role is crucial considering that most climate information provision tools are limited to international, regional and country-level spatial resolutions [43] and that Africa cannot wait for such data collation instruments to be availed as climate change is already obliterating its social, cultural and economic systems. It is in this context that local ecological knowledge can provide valuable information for climate adaptation efforts that are cost-effective, participatory, locally-relevant and are sustainable $[38,40]$. As such, participation 
processes (including the methods and platforms) for soliciting such environmental change narratives become very important when implementing climate adaptation tools.

\subsubsection{Participatory Modelling and Scenarios Building at the Rural Community Level}

The risk communication exercise is subsequently followed by participatory modelling and scenarios-building which practitioners and the local community members use to draw up climate adaptation action plans.

\section{Participatory Modelling}

Computer-based and document-based modelling are two common types of modelling used by various actors and sectors in development planning and environmental management across the world. Computer-based modelling is used to simulate different scenarios and provide climate change information particularly as they pertain to large spatial and temporal scales (e.g., IPCC Global Circulation Models, weADAPT etc.). Computer-based modelling can be participatory although it mainly requires the input of quantitative data rather than qualitative narratives of the future emanating from the local community itself. The selection of such quantitative data is guided by principles, hypotheses and assumptions derived through a subjective and qualitative process of desirable or undesirable alternative futures defined by the concerned stakeholders [15]. Exercises on computer-modelling with stakeholders have been conducted in large-scale projects such as PHOENIX, VISIONS for a Sustainable Europe (VISIONS project), Urban Lifestyles, Sustainability and Integrated Environmental Assessment (ULYSSES), and Climate Options in the Long-term (COOL) projects [18]. Findings from these projects suggest that stakeholders struggled with computer models and experienced single loop learning only (fact acquisition and consequences of actions) but did not experience triple loop/social learning that foster behavioural change [18] despite the fact that computer-modelling exercises can multiple learning opportunities.

In 2009, Mahmoud and colleagues proposed a framework for scenarios development and application that features full stakeholder participation and iteration throughout. Despite this, calls for simplified but credible model-based approaches continued [61]. These efforts are partly driven by the recognition that computer-models can be intimidating to local communities, including even the educated elite. Others have criticized computer models as been an authoritative form of knowledge that might discourage the participation of local and indigenous people. Critics add that computer models can lead to streamlining of cognitive frames and uniform forms of knowledge [18] which is the direct opposite of local ecological knowledge. Also, the cost of hardware, software and trained personnel is out of reach for many sub-Saharan African countries and more so for rural communities.

Small-scale or narrative scenarios can be developed and applied without the aid of computer models. This has been the trend followed by development cooperation organizations applying document-based climate adaptation tools in rural communities [26]. These paper-based climate adaptation tools use document-based participatory modelling to illicit small-scale (spatial and temporal) scenarios. Small-scale scenarios, at a local community level, use hands-on participatory tools that include, rich pictures, companion modelling, group model building and the future-backward scenarios analysis tool. Critical development and application of such tools is crucial although they are not high-tech. The critical development and application of small-scale scenarios hinges on the ability of practitioners and local communities to reflect on the quality and rigor of such a process. Such due diligence increases the credibility and acceptability of narrative scenarios as a decision-making technique.

\section{Scenario Building}

The Intergovernmental Panel on Climate Change [93] defines scenarios as coherent, internally consistent and plausible description of possible future state of the world. It is not a forecast, rather, 
each scenario is one alternative image of how the future can unfold. Scenarios can be either exploratory or anticipatory (see Mahmoud et al. [15] for an in-depth definition).

Table 4. Scenarios type.

\begin{tabular}{|c|c|c|c|}
\hline \multirow{2}{*}{ Scenarios } & Exploratory & Future trends & $\begin{array}{l}\text { Projective } \\
\text { Prospective }\end{array}$ \\
\hline & Anticipatory & Policy responsive & $\begin{array}{l}\text { Expert judgement } \\
\text { Stakeholder defined }\end{array}$ \\
\hline
\end{tabular}

Source: Authors' own synthesis.

According to Mahmoud et al. [15] (p. 799) "scenarios are typically used in the context of planning over long time horizons or short-term decision making that has long-term consequences" in fields such as climate change adaptation and mitigation. However, application of scenario planning in the environmental management is a new phenomenon that began in the mid-2000s and case studies of such applications can be found in Baker et al. [94], Santelmann et al. [95], and Steinitz \& McDowell [96]. Scenarios are important in environmental management, particularly in climate change adaptation, because they create a platform for decision makers and rural communities to work together and create solutions that are politically acceptable, also, this interaction allows the integration of scientific know how with local ecological knowledge. In this way, scenario planning guides and supports informed decision-making. This process of decision-making can involve exercises that challenge conventional thinking and assumptions leading to social learning $[15,26]$. Reframing conventional and commonly held assumptions, beliefs and practices is required if we are to change the patterns of consumption and production that are destroying the atmosphere. We hope that such a paradigm shift will redirect humanity towards sustainable development practices.

The majority of climate adaptation tools that were critically assessed by Nkoana et al. [20] are 'not explicit' on whether or not they conduct scenarios analysis with community members. The limited application of scenario planning in environmental planning and management is not only due to its novelty but also to the lack of guidance on how to conduct scenario planning process-a hurdle that Mahmoud et al. [15] attempt to overcome by proposing a 'formal framework for scenarios analysis'. Important lesson on scenarios planning can be drawn from Mahmoud and colleagues' work by practitioners conducting scenarios planning with local communities in a developing country context.

This framework highlights the fact that narratives or mental images can be used to develop qualitative description of scenarios for small-scale systems such as a rural community. Narratives or storylines are a communication medium used by local communities to pass on knowledge from one generation to another. Using this communication medium will encourage the participation of local communities in scenarios planning in climate adaptation efforts. Small-scale scenarios planning can be a useful collaboration, communication and planning platform for practitioners and local communities engaged in climate adaptation work. This is in direct contrast to computer-based modelling that requires the input of quantitative data and is used to produce alternative scenarios for large-scale systems such as the Global Circulation Models (GCMs) of the IPCC to predict the impact of increasing concentrations of harmful greenhouse gases in the atmosphere by the year 2100 [97].

\subsection{Assessing the Sustainability of Climate Adaptation Action Plans}

An assessment of the sustainability of climate adaptation plans is a necessary step considering what Mahmoud et al. [15] (p. 799) calls " .. planning over long time horizons or short-term decision making that has long-term consequences". Indeed, climate adaptation action plans should be vetted against increasing the maladaptation of the intended beneficiaries of development cooperation efforts. This is crucial due to the over reliance of rural communities in sub-Saharan Africa on climate sensitive natural resources that renders them vulnerable to the negative impacts of climate change. It is this reality that compels development cooperation organizations to implement climate adaptation efforts that 
mainly focus on "addressing the drivers of vulnerability" through the diversification of livelihoods, improvements in literacy, advocacy on human rights and HIV/AIDS projects and so forth $[26,98]$. However, the caveat with this logic of pursuing climate adaptation through socio-economic means might lead to maladaptation, defined by the World Bank [2] as an action or process that increases vulnerability to climate change-related hazards. Maladaptive actions and processes may include planned development initiatives that deliver short-term gains or economic benefits but lead to exacerbated vulnerability in the medium to long-term. Climate adaptation tools should aim to realize win-win adaptation, no-regret adaptation, and/or low regret adaptation [3] in order to minimize maladaptation. With this in mind, climate adaptation tools should incorporate a component of sustainability assessment as a final stage prior to the implementation of adaptation action plans. Hugé et al. [99] discusses the effectiveness of sustainability assessment in improving the quality of development cooperation efforts. Such empirical studies can feed into the incorporation of sustainability concerns in climate adaptation tools-thus improving the quality of collaboration between practitioners and the local communities.

\section{Concluding Remarks}

Climate change is threatening the livelihoods of rural communities in sub-Saharan Africa. These negative impacts of climate change are superimposed by non-climatic stressors including HIV / AIDS and poverty. Rural people continue to make decisions on a daily basis to secure their livelihoods and to protect their culture. Bilateral, multilateral and non-governmental organizations have developed and applied climate adaptation tools to support decision-making processes within rural communities in the global South. However, these adaptation tools are sometimes underpinned by worldviews which are highly divergent from and not always compatible with, the perspectives of the rural communities they seek to help. This is one of the causes that result in the limited participation of rural communities in climate adaptation efforts.

We conducted an integrative literature review exercise to identify best practices for involving rural communities in climate adaptation efforts initiated by development cooperation practitioners. We subsequently pointed out important considerations when planning, designing and implementing adaptation tools in pursuit of full participation and sustainable climate adaptation-that is, adaptation that minimizes maladaptive practices. Such a process begins with acknowledging the context within which rural communities are embedded. Issues of context can highlight daily struggles to put food on the table. These struggles preoccupy the everyday lives of rural community members on the African continent and should serve as an entry point for discussions about climate adaptation. Practitioners have to involve elders as local experts, leaders and gatekeepers when identifying stakeholders to partake in climate adaptation efforts. These elders might hold the key to the success of any adaptation effort because they are respected by the members of their own community. The training and involvement of a local champion as a part of the steering committee can assist outsiders (practitioners) to make sense of the cultural do's and don'ts within the rural community. The local champion can assist to communicate the objectives of the adaptation effort to the rural communities in a language they understand. Soliciting their informed consent in this manner will enable the local community who are potential participants to gauge the level of commitment in the adaptation effort and to manage their expectations.

The local knowledge of community members about development and environmental protection is an important aspect of context. It is well documented that rural communities all over the world observe the changes in nature. They use techniques such as climate monitoring to determine cultivation seasons and the culling of livestock and so forth. Their interaction with and knowledge of their surrounding environment shapes the worldview of members of these rural societies. These worldviews constitute the lenses through which members of a society, collectively or individually, experience and interpret the world around them. Unless they come from the same culture, often, practitioners cannot fully understand these local worldviews as they are the lived experiences of rural people but efforts should 
be made to solicit such knowledge from these communities. In the same vein, rural communities can benefit from the knowhow of practitioners on climate science. This dialogue between local and scientific knowledge systems is crucial in the context of finding solutions to complex socio-political, economic and environmental problems. Such a dialogue also enables rural communities to fully participate in adaptation action plans and take ownership post the intervention of development cooperation organizations.

The full participation of rural people in adaptation action plans requires careful, reflexive and critical application of climate adaptation tools. Subjective frameworks that improve the quality and acceptability of participation process and outcomes should be considered in a serious light. Equally, practitioners should think critically when applying methods and tools found in the PRA, CRA and VCA family. Critical and reflexive application of such methods and tools is crucial in the context of integrating local and scientific knowledge in local decisions-as it gives the former legitimacy and acceptability-especially considering the skepticism surrounding stand-alone local knowledge systems.

Last, practitioners and local community representatives should conduct a sustainability assessment exercise to assess the resilience of climate adaptation action plans against maladaptive practices that might increase the vulnerability of the intended beneficiaries in the long-term. More empirical research is required to develop participatory and sustainability assessment methods and tools that are accessible to and mainstreams the inclusion of rural communities in sub-Saharan Africa in transdisciplinary endeavors.

Acknowledgments: We thank the anonymous reviewers, whose comments greatly enriched and improved the article. Elvis Nkoana acknowledges the support of the following organizations: the European and South Africa partnership for development (EUROSA) for the 36 months PhD scholarship funding to study at the University of Antwerp. The financial assistance of the National Research Foundation (NRF) towards this research is hereby acknowledged. We acknowledge the support of the KLIMOS ACROPOLIS Research Platform on Climate Change \& Development Cooperation, funded by the VLIR UOS and ARES. Opinions expressed and conclusions arrived at, are those of the author and are not necessarily to be attributed to the NRF.

Author Contributions: All the authors contributed equally to this work.

Conflicts of Interest: The authors declare no conflict of interest.

\section{Appendix}

Abarquez, Imelda and Murshed, Zubair. 2004. Community-Based Disaster Risk Management (CBDRM): Asian Disaster Preparedness Center (ADPC). URL Link: http:/ /www.adpc.net/pdr-sea/ publications/12Handbk.pdf.

Advancing Capacity to Support Climate Change Adaptation (ACCCA). United Nations Institute for Training \& Research (UNITAR), Environnement et Développement du Tiers Monde (ENDA-TM), Stockholm Environment Institute (SEI), Climate System Analysis Group (CSAG-UCT), Global Change SysTem for Analysis Research \& Training (START), Temperate East Asia START Regional Center and Southeast Asia START Regional Center. URL Link: http:/ / start.org/programs/accca.

Adaptation Guidance Manual: United States Agency for International Development (USAID). August 2007. URL Link: http:/ / pdf.usaid.gov/pdf_docs/PNADJ990.pdf.

Adaptation Guidance Notes: World Bank. URL Link: http:/ / siteresources.worldbank.org/EXTTOOLKTT3/ Resources/3646250-1250715327143/GN8.pdf.

Adaptation Learning Mechanism (ALM): United Nations Development Programme. URL Link: http://www.undp.adaptationlearning.net/about.

Adaptation Policy Framework (APF). United Nations Framework Convention on Climate Change (UNFCCC). URL Link: http:/ / unfccc.int/adaptation/nairobi_work_programme/knowledge_ resources_and_publications/items/5501.php.

Adaptation Wizard. UK Climate Impacts Programme (UK-CIP). URL Link: http:/ / www.ukcip.org. uk/wizard/.

Adaptive Capacity Benchmarking. ESPACE (European Spatial Planning: Adapting to Climate Events) URL Link: http:/ / www.espace-project.org/index.htm. 
Africa-Adapt: URL Link: http:/ /www.africa-adapt.net/.

Assessments of Impacts and Adaptations to Climate Change (AIACC). United Nations Environment Programme (UNEP), START and the Third World Academy of Sciences (TWAS). URL Link: http: //www.aiaccproject.org/aiacc.html.

aWhere Spatial Information Systems (SIS): URL Link: http:/ /www.awhere.com/en-us/awherehome. Columbia Basin Trust. 2011. Adaptation Discovery Tool (ADT). Communities Adapting to Climate Change Initiative (CACCI). 1st edition. Columbia Basin Trust. URL Link: http:/ / adaptationresourcekit. squarespace.com/storage/Adaptation\%20Discovery\%20Tool_Draft\%20First\%20Edition_June2011.pdf. Columbia Basin Trust. 2008-2015. CBT Six Step Process. URL Link: http:/ / adaptationresourcekit. squarespace.com/six-step-planning-process/.

Climate Analysis Indicators Tool (CAIT). World Resources Institute (WRI). URL Link: http:/ /www. wri.org/project/cait/.

Climate Change Explorer tool (CCE) now Climate Information Portal (CIP). weADAPT. URL Link: http:/ / weadapt.org/knowledge-base/using-climate-information/the-climate-change-explorer-tool.

Climate Change Knowledge Portal (CCKP). World Bank. URL Link: http:/ /sdwebx.worldbank.org/ climateportal/index.cfm.

Climate Change Screening Checklist. Asian Development Bank. URL Link: www.adb.org (climate proofing tool but not publicly available).

Climate Check (includes "Climate Proofing" and "Emission Saving" tools). German Technical Cooperation (GTZ). URL Link: http:/ / www.germany-wuf4.de/dokumente/04_gtz/05_gtz_sektorthemen/ 06_klima/04.05.06.02_en_gtz_gtz2008-factsheet-climate-check.pdf.

Climate Impacts: Global and Regional Adaptation Support Platform (ci:grasp). URL Link: http: //cigrasp.pik-potsdam.de/.

Climate Risk Impacts on Sectors and Programmes (CRISP). DEW Point (UK) on behalf of DFID-decommissioned on 30th June 2012. URL Link: http:/ / africanclimate.net/en/node/7140.

Climate 1-Stop: URL Link: http:/ / arcserver4.iagt.org/climate1stop/.

Coastal Adaptation Toolkit. United States Environmental Protection Agency (EPA). URL Links:

(1) http://www.cakex.org/ (Climate Adaptation Knowledge Exchange: CAKE).

(2) http://www.csc.noaa.gov/digitalcoast/inundation/index.html (coastal inundation toolkit).

(2.1.) https:/ / www.csc.noaa.gov/digitalcoast/tools/criticalfacilities (Critical Facilities Flood Exposure Tool).

(2.2.) https://www.csc.noaa.gov/digitalcoast/tools/climatewizard (Climate Wizard).

(3) http://water.epa.gov/infrastructure/watersecurity/climate/creat.cfm (Climate Resilience Evaluation \& Awareness Tool: CREAT).

(4) http://water.epa.gov/infrastructure/watersecurity/climate/index.cfm (Climate Ready Water Utilities: CRWU).

(5) http://sarasotabay.org/slr-web-map/ (Sea Level Rise Viewer).

Community Based Adaptation Exchange (CBA-X): Eldis communities. URL Link: http:/ / community. eldis.org/cbax/.

Community-based Risk Screening Tool-Adaptation and Livelihoods (CRiSTAL). International Institute for Sustainable Development (IISD); International Union for Conservation of Nature (IUCN); Stockholm Environmental Institute (SEI); Inter-cooperation. URL Link: http://www.iisd.org/ cristaltool/.

Dazé, Angie; Ambrose, Kaia and Ehrhart, Charles. 2009. Climate Vulnerability and Capacity Assessment (CVCA) Handbook: CARE International. URL Link: http:/ / www.careclimatechange. org/cvca/CARE_CVCAHandbook.pdf.

De Dios, Honorio B and Victoriano, Ian. 2002. Participatory Capacities and Vulnerabilities Assessment (PCVA): Finding the Link between Disasters and Development. Oxfam. 
URL Link: http:/ / policy-practice.oxfam.org.uk/publications/participatory-capacities-and-vulnerabilitiesassessment-finding-the-link-betwee-112522.

Hands-on Energy Adaptation Toolkit (HEAT): Energy Sector Management Assistance Program (ESMAP). URL Link: http://www.esmap.org/esmap/node/312.

Hansford, Bob and Venton, Paul. 2010. Participatory Assessment of Disaster Risk (PADR). ROOTS 9: Reducing risk of disaster in our communities. 2nd edition. TEARFUND. UK. URL Link: http:/ / tilz.tearfund.org/ /media/Files/TILZ/Publications/ROOTS/English/Disaster/ ROOTS\%209\%20Reducing\%20risk\%20of\%20disaster.pdf.

International Panel on Climate Change (IPCC). 1992. IPCC Common Methodology. URL Link: http://unfccc.int/files/adaptation/methodologies_for/vulnerability_and_adaptation/application/ pdf/ipcc_common_methodology.pdf.

Luneta, Mayfourth D. 2007. Child-Oriented Participatory Risk Assessment \& Planning (COPRAP). ProVention Consortium and the Asian Disaster Preparedness Center (ADPC). URL Link: http://www. gdnonline.org/resources/ADPC_CDP_COPRAP_toolkit.pdf.

Livelihood Assessment Tool-kit (LAT). Food and Agriculture Organization of the United Nations (FAO) and International Labour Organization (ILO), April 2009. URL Link: http:/ /www.fao.org/ fileadmin/templates/tc/tce/pdf/LAT_Brochure_LoRes.pdf.

National Adaptation Programmes of Actions Platform (NAPA). United Nations Institute for Training and Research, Climate Change Programme (UNITAR); UNFCCC-United Nations Framework Convention on Climate Change; GEF-Global Environment Facility; GEF Implementing and Executing Agencies include UNDP-United Nations Development Programme; UNEP - United Nations Environment Programme; World Bank; and International Fund for Agriculture and Development. URL Link: http:/ / www.napa-pana.org/.

NCAP. 2007. Climate Quick Scan. The Netherlands Climate Assistance Programme (NCAP) -Dutch Ministry of Foreign Affairs (DGIS). March 2007. URL Links: www.nlcap.net or http:/ / www.nlcap.net/ uploads/media/Poverty_Reduction_at_Risk_Synthesis_Report.v1.pdf.

Opportunities and Risks of Climate Change and Disasters (ORCHID). Institute for Development Studies (IDS); UK Department for International Development (DFID). URL Link: http:/ / tinyurl.com/ ccorchid.

Participatory Vulnerability Analysis (PVA). ActionAid International. URL Link: http://www. actionaid.org.uk/100262/participatory_vulnerability_analysis.html.

Preparedness for Climate Change. Red Cross/Red Crescent. URL Link: http:/ /www.climatecentre.org/ site/preparedness-for-climate-change-programme and http:/ / www.climatecentre.org/downloads/File/ programs/Final\%20PFCC\%20General\%20Assembly\%20Document\%20with\%20renewed\%20table.pdf.

Providing Regional Climates for Impacts Studies (PRECIS) Regional Climate Modelling System. UK Met Office Hadley Centre. URL Link: http:/ /www.metoffice.gov.uk/precis/.

Regmi, Bimal Raj; Morcrette, Alex; Paudyal, Apar; Bastakotti, Rishi; and Pradhan, Sibongile. 2010. Participatory Tools and Techniques for Assessing Climate Change Impacts and Exploring Adaptation Options (Participatory Toolkit for Impacts and Adaptation). UKAID and Livelihoods \& Forestry Programme (LFP): Nepal. URL Link: http:/ / www.forestrynepal.org/project/40.

SERVIR- Regional Visualization and Mapping System. United States Agency for International Development (USAID), National Aeronautic Space Administration (NASA), Water Center for the Humid Tropics of Latin America and the Caribbean (CATHALAC), Institute for the Application of Geospatial Technology (IAGT). URL Link: http:/ / www.servir.net/.

Statistical Downscaling Model 4.2 (SDSM). UK Environmental Agency. URL Link: http:/ / co-public. lboro.ac.uk/cocwd/SDSM/.

UNEP Handbook on Methods for Climate Change Impact Assessment and Adaptation Strategies. United Nations Framework Convention on Climate Change (UNFCCC). URL Link: http:/ / unfccc.int/ adaptation/nairobi_work_programme/knowledge_resources_and_publications/items/5503.php. 
Vulnerability Mapping and Poverty. Department for International Development (DFID); International Livestock Research Institute (ILRI); Energy \& Resources Institute (TERI); African Centre for Technology Studies (ACTS) URL Link: http:/ / www.dfid.gov.uk/research/mapping-climate.pdf. Wiggins, Mike. 2012. Climate change and Environmental Degradation Risk and adaptation Assessment (CEDRA) (2nd edition). TEARFUND: UK. URL Link: http://tilz.tearfund.org/ /media/ Files/TILZ/Topics/Environmental\%20Sustainability/CEDRA\%20version\%202/01CEDRA_Book_ And_Forms/CEDRA_main_document.pdf.

Wiki weADAPT: URL Link: http://weadapt.org/placemarks/earth.

\section{References}

1. Intergovernmental Panel on Climate Change (IPCC). Managing the Risks of Extreme Events and Disasters to Advance Climate Change Adaptation; A Special Report of Working Groups I and II of the Intergovernmental Panel on Climate Change; Cambridge University Press: Cambridge, UK, 2012; pp. 1-582.

2. World Bank. Mainstreaming Adaptation to Climate Change in Agriculture and Natural Resources Management Projects; World Bank Group: New York, NY, USA, 2012; pp. 1-24.

3. United Kingdom Climate Information Programme (UKCIP). Identifying Adaptation Options; United Kingdom Climate Information Programme (UKCIP): Oxford, UK, 2007; pp. 1-35.

4. United Nations Framework Convention on Climate Change (UNFCCC). Paris Agreement; United Nations Framework Convention on Climate Change (UNFCCC): Paris, France, 2015; pp. 1-27.

5. Intergovernmental Panel on Climate Change (IPCC). Climate Change 2017: Impacts, Adaptation and Vulnerability; Working Group II Contribution to the Fourth Assessment Report of the Intergovernmental Panel on Climate Change; Intergovernmental Panel on Climate Change (IPCC): Geneva, Switzerland, 2007; pp. 1-987.

6. Van Aalst, M.K.; Cannon, T.; Burton, I. Community level adaptation to climate change: The potential role of participatory community risk assessment. Glob. Environ. Chang. 2008, 18, 165-179. [CrossRef]

7. McIntosh, B.S.; Ascough, J.C.; Twery, M.; Chew, J.; Elmahdi, A.; Haase, D.; Harou, J.J.; Hepting, D.; Cuddy, S.; Jakeman, A.J.; et al. Environmental decision support systems (EDSS) development-Challenges and best practices. Environ. Model. Softw. 2011, 26, 1389-1402. [CrossRef]

8. Abbas, A.; Amjath-Babu, T.S.; Kachele, H.; Muller, K. Participatory adaptation to climate extremes: An assessment of households willingness to contribute labor for flood risk mitigation in Pakistan. J. Water Clim. Chang. 2016, 7, 621-636. [CrossRef]

9. Abbas, A.; Amjath-Babu, T.S.; Kächele, H.; Usman, M.; Müller, K. An overview of flood mitigation strategy and research support in South Asia: Implications for sustainable flood risk management. Int. J. Sustain. Dev. World Ecol. 2016, 23, 98-111. [CrossRef]

10. Benson, C.; Twigg, J.; Rossetto, T. Tools for Mainstreaming Disaster Risk Reduction: Guidance Notes for Development Organisations; ProVention Consortium: Geneva, Switzerland, 2016; pp. 1-184.

11. Adelle, C. Contexualising the tool development process through a knowledge brokering approach: The case of climate change adaptation and agriculture. Environ. Sci. Policy 2015, 51, 316-324. [CrossRef]

12. Dubois, C.; Cloutier, G.; Potvin, A.; Adolphe, L.; Joerin, F. Design support tools to sustain climate change adaptation at the local level: A review and reflection on their suitability. Front. Archit. Res. 2015, 4, 1-11. [CrossRef]

13. Jakeman, A.J.; Letcher, R.A.; Norton, J.P. Ten iterative steps in development and evaluation of environmental models. Environ. Model. Softw. 2006, 21, 602-614. [CrossRef]

14. Lieske, D.J. Coping with climate change: The role of spatial decision support tools in facilitating community adaptation. Environ. Model. Softw. 2015, 68, 98-109. [CrossRef]

15. Mahmoud, M.; Liu, Y.; Hartmann, H.; Stewart, S.; Wagener, T.; Semmens, D.; Stewart, R.; Gupta, H.; Dominguez, D.; Dominguez, F.; et al. A formal framework for scenario development in support of environmental decision-making. Environ. Model. Softw. 2009, 24, 798-808. [CrossRef]

16. Reed, M.S.; Kenter, J.; Bonn, A.; Broad, K.; Burt, T.P.; Fazey, I.R.; Fraser, E.D.G.; Hubacek, K.; Nainggolan, D.; Quinn, C.H.; et al. Participatory scenario development for environmental management: A methodological framework illustrated with experience from the UK uplands. J. Environ. Manag. 2013, 128, 345-362. [CrossRef] [PubMed] 
17. Schlumpf, C.; Behringer, J.; Durrenberger, G.; Pahl-Wostl, C. The personal $\mathrm{CO}_{2}$ calculator: A modeling tool for Participatory Integrated Assessment methods. Environ. Model. Assess. 1999, 4, 1-12. [CrossRef]

18. Siebenhüner, B.; Barth, V. The role of computer modelling in participatory integrated assessments. Environ. Impact Assess. Rev. 2005, 25, 367-389. [CrossRef]

19. Schmidt, L.; Pröpper, M. Transdisciplinarity as a real-world challenge: A case study on a North-South collaboration. Sustain. Sci. 2017, 12, 365-379. [CrossRef]

20. Jahn, T.; Bergmann, M.; Keil, F. Transdisciplinarity: Between mainstreaming and marginalization. Ecol. Econ. 2012, 79, 1-10. [CrossRef]

21. Schuck-Zöller, S.; Cortekar, J.; Jacob, D. Evaluating co-creation of knowledge: From quality criteria and indicators to methods. Adv. Sci. Res. 2017, 14, 305-312. [CrossRef]

22. Adler, C.; Hirsch Hadorn, G.; Breu, T.; Wiesmann, U.; Pohl, C. Conceptualizing the transfer of knowledge across cases in transdisciplinary research. Sustain. Sci. 2018, 13, 179-190. [CrossRef]

23. Schneider, F.; Buser, T. Promising degrees of stakeholder interaction in research for sustainable development. Sustain. Sci. 2018, 13, 129-142. [CrossRef]

24. United Nations Framework Convention on Climate Change (UNFCCC). Compendium on Methods and Tools to Evaluate Impacts of, and Vulnerability and Adaptation to, Climate Change; United Nations Framework Convention on Climate Change (UNFCCC): Bonn, Germany, 2005; pp. 1-155.

25. United Nations Framework Convention on Climate Change (UNFCCC). Synthesis of Information and Views on Methods and Tools Submitted by Parties and Relevant Organizations; United Nations Framework Convention on Climate Change (UNFCCC): Nairobi, Kenya, 2007; pp. 1-17.

26. Nkoana, E.M.; Waas, T.; Verbruggen, A.; Burman, C.J.; Hugé, J. Analytic framework for assessing participation processes and outcomes of climate change adaptation tools. Environ. Dev. Sustain. 2017, 19, 1731-1760. [CrossRef]

27. Kohtala, C. Addressing sustainability in research on distributed production: An integrated literature review. J. Clean. Prod. 2015, 106, 654-668. [CrossRef]

28. Whittemore, R.; Knafl, K. The integrative review: Updated methodology. J. Adv. Nurs. 2005, 52, 546-553. [CrossRef] [PubMed]

29. Kitchenham, B. Procedures for Performing Systematic Reviews; Keele University: Keele, UK, 2004.

30. Flick, U. An Introduction to Qualitative Research, 5th ed.; SAGE Publications Ltd.: London, UK, 2014.

31. Matthies, M.; Giupponi, C.; Ostendorf, B. Environmental decision support systems: Current issues, methods and tools. Environ. Model. Softw. 2007, 22, 123-127. [CrossRef]

32. Sullivan, T. Evaluating Environmental Decision Support Tools; Brookhaven National Laboratory: New York, NY, USA, 2002.

33. Huntington, H.; Fox, S. The Changing Arctic: Indigenous Perspectives; Arctic Climate Change Impact Assessment; Arctic Council and the International Arctic Science Committee: Reykjavik, Iceland, 2005; pp. 1-38.

34. Macchi, M. Indigenous and Traditional Peoples and Climate Change; International Union for Conservation of Nature: Gland, Switzerland, 2008; pp. 1-66.

35. United Nations Educational, Scientific and Cultural Organization (UNESCO). Learning and Knowing in Indigenous Socities Today; United Nations Educational, Scientific and Cultural Organization (UNESCO): Paris, France, 2009.

36. Food and Agriculture Organization of the United Nations (FAO). FAO Policy on Indigenous and Tribal Peoples; Food and Agriculture Organization of the United Nations: Rome, Italy, 2010; pp. 1-44.

37. Van Opstal, M.; Hugé, J. Knowledge for sustainable development: A worldviews perspective. Environ. Dev. Sustain. 2013, 15, 687-709. [CrossRef]

38. Nkomwa, E.C.; Joshua, M.K.; Ngongondo, C.; Monjerezi, M.; Chipungu, F. Assessing indigenous knowledge systems and climate change adaptation strategies in agriculture: A case study of Chagaka Village, Chikhwawa, Southern Malawi. Phys. Chem. Earth Parts ABC 2014, 67-69, 164-172. [CrossRef]

39. Codjoe, S.N.A.; Owusu, G.; Burkett, V. Perception, experience, and indigenous knowledge of climate change and variability: The case of Accra, a sub-Saharan African city. Reg. Environ. Chang. 2014, 14, 369-383. [CrossRef]

40. Egeru, A. Role of indigenous knowledge in climate change adaptation: A case study of the Teso Sub-Region, Eastern Uganda. Indian J. Tradit. Knowl. 2012, 11, 217-224. 
41. Alexander, C.; Bynum, N.; Johnson, E.; King, U.; Mustonen, T.; Neofotis, P.; Oettlé, N.; Rosenzweig, C.; Sakakibara, C.; Shadrin, V.; et al. Linking Indigenous and Scientific Knowledge of Climate Change. BioScience 2011, 61, 477-484. [CrossRef]

42. Mengistu, D.K. Farmers' perception and knowledge on climate change and their coping strategies to the related hazards: Case study from Adiha, central Tigray, Ethiopia. Agric. Sci. 2011, 2, 138-145. [CrossRef]

43. Ifejika Speranza, C.; Kiteme, B.; Ambenje, P.; Wiesmann, U.; Makali, S. Indigenous knowledge related to climate variability and change: Insights from droughts in semi-arid areas of former Makueni District, Kenya. Clim. Chang. 2010, 100, 295-315. [CrossRef]

44. Nielsen, J.Ø.; Reenberg, A. Cultural barriers to climate change adaptation: A case study from Northern Burkina Faso. Glob. Environ. Chang. 2010, 20, 142-152. [CrossRef]

45. Nyong, A.; Adesina, F.; Osman Elasha, B. The value of indigenous knowledge in climate change mitigation and adaptation strategies in the African Sahel. Mitig. Adapt. Strateg. Glob. Chang. 2007, 12, 787-797. [CrossRef]

46. Roncoli, C.; Ingram, K.; Kirshen, P. The costs and risks of coping with drought: Livelihood impacts and farmers' responses in Burkina Faso. Clim. Res. 2001, 19, 119-132. [CrossRef]

47. Antweiler, C. Local knowledge and local knowing. An anthropological analysis of contested cultural products in the context of development. Anthropos 1998, 19, 469-494.

48. Cooper, P.J.M.; Dimes, J.; Rao, K.P.C.; Shapiro, B.; Shiferaw, B.; Twomlow, S. Coping better with current climatic variability in the rain-fed farming systems of sub-Saharan Africa: An essential first step in adapting to future climate change? Agric. Ecosyst. Environ. 2008, 126, 24-35. [CrossRef]

49. Thomas, D.S.G.; Twyman, C. Equity and justice in climate change adaptation amongst natural-resourcedependent societies. Glob. Environ. Chang. 2005, 15, 115-124. [CrossRef]

50. Yamano, T.; Jayne, T. Measuring the Impacts of Working-Age Adult Mortality on Small-Scale Farm Households in Kenya. World Dev. 2004, 32, 91-119. [CrossRef]

51. Schipper, E.L.F. Climate Change Adaptation and Development: Exploring the Linkages; Tyndall Centre for Climate Change Research: Norwich, UK, 2007; pp. 1-20.

52. National Planning Commission. National Development Plan 2030: Our Future-Make It Work; Government Printing Works: Pretoria, South Africa, 2012.

53. Dekens, J. Local Knowledge for Disaster Preparedness: A Literature Review; International Centre for Integrated Mountain Development: Kathmandu, Nepal, 2007.

54. Lemos, M.C.; Finan, T.J.; Fox, R.W.; Nelson, D.R.; Tucker, J. The use of seasonal climate forecasting in policymaking: Lessons from Northeast Brazil. Clim. Chang. 2002, 55, 479-507. [CrossRef]

55. Luseno, W.K.; McPeak, J.G.; Barrett, C.B.; Little, P.D.; Gebru, G. Assessing the Value of Climate Forecast Information for Pastoralists: Evidence from Southern Ethiopia and Northern Kenya. World Dev. 2003, 31, 1477-1494. [CrossRef]

56. Roberts, D. Thinking globally, acting locally-Institutionalizing climate change at the local government level in Durban, South Africa. Environ. Urban. 2008, 20, 521-537. [CrossRef]

57. Anguelovski, I.; Chu, E.; Carmin, J. Variations in approaches to urban climate adaptation: Experiences and experimentation from the global South. Glob. Environ. Chang. 2014, 27, 156-167. [CrossRef]

58. Roberts, D.; O'Donoghue, S. Urban environmental challenges and climate change action in Durban, South Africa. Environ. Urban. 2013, 25, 299-319. [CrossRef]

59. Voinov, A.; Bousquet, F. Modelling with stakeholders. Environ. Model. Softw. 2010, 25, 1268-1281. [CrossRef]

60. Salter, J.; Robinson, J.; Wiek, A. Participatory methods of integrated assessment-A review. Rev. Clim. Chang. 2010, 1, 697-717. [CrossRef]

61. Lindenberg, M.M.; Crosby, B.L. Managing Development: The Political Dimension; Kumarian Press: West Hartford, CT, USA, 1981.

62. Freeman, A.M. Depletable externalities and pigouvian taxation. J. Environ. Econ. Manag. 1984, 11, $173-179$. [CrossRef]

63. Freeman, R. Strategic Management: A Stakeholder's Approach; Cambridge University Press: New York, NY, USA, 1984; ISBN 978-0-521-15174-0.

64. Goodpaster, K. Business ethics and stakeholder analysis. Bus. Ethics Q. 1991, 1, 53-73. [CrossRef]

65. Savage, G.T.; Nix, T.W.; Whitehead, C.J.; Blair, J.D. Strategies for assessing and managing organizational stakeholders. Executive 1991, 5, 61-75. [CrossRef] 
66. Clarkson, M.E. A Stakeholder Framework for Analyzing and Evaluating Corporate Social Performance. Acad. Manag. Rev. 1995, 20, 92-117. [CrossRef]

67. Mitchell, R.K.; Agle, B.R.; Wood, D.J. Toward A Theory of Stakeholder Identification and Salience: Defining the Principle of Who and What Really Counts. Acad. Manag. Rev. 1997, 22, 853-886. [CrossRef]

68. Rowley, T.J. Moving Beyond Dyadic Ties: A Network Theory of Stakeholder Influences. Acad. Manag. Rev. 1997, 22, 887-910. [CrossRef]

69. Scholes, E.; Clutterbuck, D. Communication with stakeholders: An integrated approach. Long Range Plan. 1998, 31, 227-238. [CrossRef]

70. Kamann, D.-J.F. Organizational design in public procurement: A stakeholder approach. J. Purch. Supply Manag. 2007, 13, 127-136. [CrossRef]

71. Chevalier, J.M.; Buckles, D. Social Analysis Systems 2 (SAS2): A Guide to Collaborative Inquiry and Social Engagement; SAGE Publications: New Delhi, India; Thousand Oaks, CA, USA, 2008; ISBN 978-81-7829-890-0.

72. Fassin, Y. The Stakeholder Model Refined. J. Bus. Ethics 2009, 84, 113-135. [CrossRef]

73. Dryzek, J.S.; Berejikian, J. Reconstructive Democratic Theory. Am. Polit. Sci. Rev. 1993, 87, 48-60. [CrossRef]

74. Barry, J.; Proops, J. Seeking sustainability discourses with Q methodology. Ecol. Econ. 1999, 28, 337-345. [CrossRef]

75. Ockwell, D.G. 'Opening up' policy to reflexive appraisal: A role for Q Methodology? A case study of fire management in Cape York, Australia. Policy Sci. 2008, 41, 263-292. [CrossRef]

76. Frantzi, S.; Carter, N.T.; Lovett, J.C. Exploring discourses on international environmental regime effectiveness with Q methodology: A case study of the Mediterranean Action Plan. J. Environ. Manag. 2009, 90, 177-186. [CrossRef] [PubMed]

77. Rajé, F. Using Q methodology to develop more perceptive insights on transport and social inclusion. Transp. Policy 2007, 14, 467-477. [CrossRef]

78. Cuppen, E.; Breukers, S.; Hisschemöller, M.; Bergsma, E. Q methodology to select participants for a stakeholder dialogue on energy options from biomass in the Netherlands. Ecol. Econ. 2010, 69, 579-591. [CrossRef]

79. Hugé, J.; Van de Velde, K.; Benitez-Capistros, F.; Japay, H.J.; Satyanarayana, B.; Ishak, M.N.; Quispe-Zuniga, M.; Lokman, B.H.M.; Sulong, I.; Koedam, N.; et al. Mapping discourse using Q methdology in Matang Mangrove Forest, Malaysia. J. Environ. Manag. 2016, 183, 988-997. [CrossRef] [PubMed]

80. Ajibade, L.T. In search for methodology for the collection and evaluation of farmers' indigenous environmental knowledge. Indilinga Afr. J. Indig. Knowl. Syst. 2003, 2, 99-105.

81. Adebo, S. Training Manual on Participatory Rural Appraisal. 2000. http://www.fsnnetwork.org/sites/ default/files/pra_guide.pdf (accessed on 7 March 2018).

82. Chambers, R. Rural Development: Putting the Last First; Longmans: London, UK, 1983.

83. International Federation of Red Cross and Red Crescent (IFRC). Vulnerability and Capacity Assessment: An International Federation Guide; International Federation of Red Cross and Red Crescent (IFRC): Geneva, Switzerland, 1999.

84. Chiwaka, E.; Yates, R. Participatory Vulnerability Analysis: A Step-by-Step Guideline for Field Staff. 2005. Available online: https://www.actionaid.org.uk/sites/default/files/doc_lib/108_1_participatory_ vulnerability_analysis_guide.pdf (accessed 7 March 2018).

85. Bell, S.; Morse, S. Rich pictures: A means to explore the 'sustainable mind'? Sustain. Dev. 2013, $21,30-47$. [CrossRef]

86. Muro, M.; Jeffrey, P. A critical review of the theory and application of social learning in participatory natural resource management processes. J. Environ. Plan. Manag. 2008, 51, 325-344. [CrossRef]

87. Glaas, E.; Gammelgaard Ballantyne, A.; Neset, T.-S.; Linnér, B.-O.; Navarra, C.; Johansson, J.; Opach, T.; Rød, J.K.; Goodsite, M.E. Facilitating climate change adaptation through communication: Insights from the development of a visualization tool. Energy Res. Soc. Sci. 2015, 10, 57-61. [CrossRef]

88. Nicholson-Cole, S.A. Representing climate change futures: A critique on the use of images for visual communication. Comput. Environ. Urban Syst. 2005, 29, 255-273. [CrossRef]

89. Grothmann, T.; Patt, A. Adaptive capacity and human cognition: The process of individual adaptation to climate change. Glob. Environ. Chang. 2005, 15, 199-213. [CrossRef]

90. Green, D.; Raygorodetsky, G. Indigenous knowledge of a changing climate. Clim. Chang. 2010, 100, $239-242$. [CrossRef] 
91. Orlove, B.; Roncoli, C.; Kabugo, M.; Majugu, A. Indigenous climate knowledge in southern Uganda: The multiple components of a dynamic regional system. Clim. Chang. 2010, 100, 243-265. [CrossRef]

92. Lema, M.A.; Majule, A.E. Impacts of climate change, variability and adaptation strategies on agriculture in semi-arid areas of Tanzania: The case of Manyoni District in Singida Region, Tanzania. Afr. J. Environ. Sci. Technol. 2009, 3, 206-218. [CrossRef]

93. IPCC Annex II: Glossary. 2014. Available online: https://www.ipcc.ch/pdf/assessment-report/ar5/wg2/ WGIIAR5-AnnexII_FINAL.pdf (accessed 7 March 2018).

94. Baker, J.P.; Hulse, D.W.; Gregory, S.V.; White, D.; Van Sickle, J.; Berger, P.A.; Dole, D.; Schumaker, N.H. Alternative Futures for the Willamette River Basin, Oregon. Ecol. Appl. 2004, 14, 313-324. [CrossRef]

95. Santelmann, M.; Freemark, K.; White, D.; Nassauer, J.; Clark, M.; Danielson, B.; Eilers, J.; Cruse, R.M.; Galatowitsch, S.; Polasky, S.; et al. Applying Ecological Principles to Land-Use Decision Making in Agricultural Watersheds. In Applying Ecological Principles to Land Management; Dale, V.H., Haeuber, R.A., Eds.; Springer: New York, NY, USA, 2001; pp. 226-252, ISBN 978-0-387-95100-3.

96. Steinitz, C.; McDowell, S. Alternative Futures for Monroe County, Pennsylvania: A Case Study in Applying Ecological Principles. In Applying Ecological Principles to Land Management; Dale, V.H., Haeuber, R.A., Eds.; Springer: New York, NY, USA, 2001; pp. 165-193, ISBN 978-0-387-95100-3.

97. Schneider, S.H. Can we estimate the likelihood of climatic changes at 2100? Clim. Chang. 2002, 52, 441-451. [CrossRef]

98. McGray, H.; Hammill, A.; Bradley, R.; Schipper, E.L.F.; Parry, J.-E. Weathering the Storm-Options for Framing Adaptation and Development; World Resources Institute: Washington, DC, USA, 2007; pp. 1-66.

99. Hugé, J.; Mukherjee, N.; Fertel, C.; Waaub, J.-P.; Block, T.; Waas, T.; Koedam, N.; Dahdouh-Guebas, F. Conceptualizing the effectiveness of sustainability assessment in Development Cooperation. Sustainability 2015, 7, 5735-5751. [CrossRef]

(C) 2018 by the authors. Licensee MDPI, Basel, Switzerland. This article is an open access article distributed under the terms and conditions of the Creative Commons Attribution (CC BY) license (http:/ / creativecommons.org/licenses/by/4.0/). 